\title{
PATENT REEXAMINATION'S PROBLEM: THE POWER TO AMEND
}

\author{
Michael J. MAURIEL
}

INTRODUCTION

The federal judiciary's exclusive reign over questions of patent validity ended in 1980 when Congress created the process of patent reexamination. ${ }^{1}$ Patent reexamination is conducted by the Patent and Trademark Office (PTO) after a "substantial new question of patentability" regarding an existing patent has been raised. ${ }^{2}$ This "question" may be raised by any person outside the PTO, including the patent's owner, or by the PTO itself. $^{3}$ Reexamination allows the PTO to determine the validity of existing patents; the PTO may, through this process, confirm the validity of or cancel individual patent claims. ${ }^{4}$ Reexamination also grants the PTO, at the patentee's request, the power to amend individual patent claims. ${ }^{5}$

Congress intended reexamination to "permit efficient resolution of questions about the validity of issued patents without recourse to expensive and lengthy [validity] litigation." Congress's

1. See Act of Dec. 12, 1980, 35 U.S.C. $\S \S 301-307$ (1994).

2. 35 U.S.C. $\$ 303(a)$.

3. Id. $\S \S 302-303$.

4. A patent "claim" is a written statement that "point[s] out what the invention is in such a way as to distinguish it froin what was previously known, i.e., the prior art ...." Robert L. HARMON, PATENTS AND THE FEDERAL CIRCUIT 7 (3d ed. 1994). A patent is made up of one or more claims. 35 U.S.C. $\& 112$ (1994). For ease of communication, one often speaks of a patent's validity, yet the question of a patent's validity is really a question of the validity of a patent's mdividual claims. The claims of a patent have legal force independent of each other. Thus, if a patent has ten claims, even if a court or the PTO finds that nine of the claims are invalid, the remaining claim may still be enforced against all who infringe it. See HARMON, supra, at 195 ("One is liable for patent infringement if a single claim be infringed.").

5. See 35 U.S.C. $\$ 307$.

6. H.R. REP. No. 96-1307, pt. 1, at 3-4 (1980), reprinted in 1980 U.S.C.C.A.N. $6460,6462-63$. Consistent with practioners' usage, the report uses the saine term, "infringement litigation," for two different aspects of patent litigation: validity and infringement. A court's ruling on validity determines whether or not the patent is enforceable; a court's rubing on infringement determines whether or not someone has wrongfully violated rights flowing from the patent grant. 
use of the phrase "without recourse" suggests the hope that reexamination would be used as an alternative, rather than as a supplement, to vahidity hitigation. In addition, by providing reexamination as an alternative to validity hitigation, Congress sought to "assur[e] the kind of certainty about patent vahidity which is a necessary ingredient of sound investment decisions."7

But reexamination must be adequately utilized in order to fulfill its goals. Since its inception it has been underutilized. Congress expected that patent reexamination would be used approximately 2,000 times per year; as of 1992, though, reexaminations were occurring only about 350 times per year. ${ }^{8}$ Moreover, when reexamination is used, it is often used in ways Congress did not anticipate. Reexamination was intended as a substitute for vahdity litigation, not as a procedural add-on to validity litigation. ${ }^{9}$ In practice, lowever, parties are requesting reexamination in addition to-not instead of-bringing patent validity issues to district courts. ${ }^{10}$

Congress seeks to address the problems of underutilization and mis-utilization with the Patent Reexamination Reform Act of 1995, currently pending in the Senate. ${ }^{11}$ The Act encourages third-party participation in the reexamination process and discourages the use of reexamination as an adjunct to vahidity hitigation. ${ }^{12}$ But Congress is mistaken if it believes that these reforms will get reexamination back on track as a viable alternative to litigation and a way to increase certainty about patent validity. This Note argues that these goals will remain thwarted by a particular aspect of reexamination procedure: the power to amend claims.

In this Note, a similar use of the term "infringement litigation" would be confusing, since reexamination replaces judicial determinations of validity only. In fact, the PTO never makes determinations regarding whether or not a patent has been infringed. Therefore, although "infringement litigation" typically refers to determinations of both validity and infringement, this Note uses the more specific "validity litigation" to clarify the discussion of reexamination's role.

7. Id. at 4 .

8. See Marvin Motsenbocker, Proposal to Change the Patent Reexamination Statute to Eliminate Unnecessary Litigation, 27 J. MARSHALL L. REV. 887, 887 n.1 (1994).

9. See supra text accompanying note 6 .

10. See, e.g., Motsenbocker, supra note 8 , at 894 (referring to defendant who requested reexamination four years after the commencement of litigation); Stryker, Inc. v. Intermedics Orthopedics, Inc., 891 F. Supp. 751, 802 (E.D.N.Y. 1995) (referring to reexamination which was ongoing at the time of trial).

11. See S. 1070, 104th Cong. (1995).

12. See infra Part $\mathrm{I}$. 
Part I examines the 1995 Reform Act and points out the Act's failure to address the two main problems created by the power to amend claims. Part II describes the first such problem. The power to amend claims leads the PTO to approach reexamination as an interested party rather than a disinterested one. Specifically, reexamination with the possibility of amendment allows the PTO to create, or more accurately recreate, the patent. Such a shepherding role contradicts the purely evaluative role the PTO must play if reexamination is to serve as a genuine alternative to litigation. Part III describes a second problem: the power to ainend has fostered claim-interpretation standards in reexamination that differ from the claim-interpretation standards applied in litigation. Because of these dual standards, patent disputes may turn on the choice of forum rather than on the merits of a particular case. Part III also explains how the power to amend claims increases rather than decreases uncertainty over patent validity. Part IV argues that the power to amend claims should be repealed in order for patent reexamination to serve Congress's original goals of reducing litigation and increasing certainty about patent validity.

\section{THE 1995 REFORM ACT}

The Patent Reexamination Reform Act of 1995 echoes the sentiments of recent commentators whose calls for reform have focused on increasing the participation of third-party requestors to solve the problem of underutilization. ${ }^{13} \mathrm{~A}$ third-party requestor is anyone other than the patentee or the PTO who requests reexamination of a patent. After requesting reexamination, this party may also reply to the patentee's initial statement to the PTO. ${ }^{14}$ The third-party's involveinent in reexamination, lowever, ends there. A third party cannot respond to later statements made by the patentee to the PTO and the third party camot appeal PTO reexamination decisions. ${ }^{15}$ The Reform Act would increase third-party par-

13. See, e.g., 1994-95 ABA SEC. OF INTELL. Prop. L. ANN. REP. 94 (1995) [hereinafter ANNUAL REPORT]; Shannon M. Casey, The Patent Reexamination Reform Act of 1994: A New Era of Third Party Participation, 2 J. INTELl. Prop. L. 559, 567 (1995); Motsenbocker, supra note 8 , at 898.

14. See 35 U.S.C. $\S \S 302,304$ (1994).

15. See id. $\S 305$ (incorporating the procedures of 35 U.S.C. $\S \S 132-133$ (1994) which do not include third-parties); id. $\$ 306$ (providing only for appeals made by the patent owner). 
ticipation in two ways. First, third parties would be able to reply to each statement made by the patentee to the PTO during reexamination. ${ }^{16}$ Second, third parties would be able to appeal initial reexamination decisions within the PTO and would be able to appeal final PTO decisions to the Court of Appeals for the Federal Circuit. ${ }^{17}$

The Reform Act also addresses the problem of misutilization. The bill would codify a principle of collateral estoppel that would prevent a party who fails to invalidate a patent in a civil action from "rehitigating" the patent's validity in a later or concurrent reexamination proceeding. ${ }^{18}$ Thus, although reexamination and litigation would still be able to proceed sinultaneously, they could not be mamtained by parties to the litigation after a district court's entry of judgment. ${ }^{19}$

These attempts to increase third-party participation and codify collateral estoppel are a step in the right direction. Patent reexammation was originally intended to provide an alternative to validity litigation. ${ }^{20}$ By allowing third parties greater participation, patent reexamination would more readily serve the dispute-resolution function of validity litigation. ${ }^{21}$ By codifying prohibitions against relitigating issues, Congress would send a message that reexamination is not merely another weapon which parties may utilize as a litigation "add-on." These reforms are, however, insufficient in and of themselves to make reexamination a viable and attractive alternative to validity litigation. Congress must also address a more fundamental source of reexamination's ills: the power to amend claims.

16. See S. 1070, 104th Cong. § 3(d) (1995).

17. See id. \& 3(e).

18. See id. \& 3(f).

19. Id.

20. See H.R. REP. No. 96-1307, pt. 1, at 3-4 (1980), reprinted in 1980 U.S.C.C.A.N. $6460,6462-63$.

21. Supporters of the proposed legislation hope that third parties who would otherwise settle their disputes with patentees in court will, if reexamination reform allows them increased participation, choose instead to settle their disputes with patentees in the PTO. See 141 CONG. REC. S10,655, S10,656 (daily ed. July 25, 1995) (statement of Sen. Hatch) (stating that "meaningful participation" by third parties "will make the reexamination system an attractive and cost-effective altemative to expensive patent litigation"). 


\section{The Power to Amend AND ReEXAmination's CONFLICTING ROLES}

The Federal Circuit views litigation and reexamination as "distinct proceedings, with distinct parties, purposes, procedures, and outcomes."22 During reexamination, the patentee may propose claim amendinents in response to the initial order granting reexamination and in response to the examiner's office actions. ${ }^{23}$ The PTO examiner then has the power to amend the patentee's claims, as long as the scope of the claims is not broadened. ${ }^{24}$ It is this power to amend claims that, according to the Federal Circuit, "distinguishes proceedings before the PTO from proceedings in federal district courts."25

Although a patentee can propose changes to her patent's claims during reexamination, she calmot propose changes to her patent's claims during validity litigation. The whole purpose of sucli litigation is to determine the patent's validity. This validity determination turns, in large part, on liow the court interprets the patent's claims. To allow a patentee to change her claims during a trial would be similar to allowimg a contract defendant to change the language of the contract while the court was in the inidst of interpreting it.

The power to amend claims during reexamination suggests that the proceeding must, as the court stated in In re Etter, have a function distinct from the purely evaluative role of a validity trial. That role may be inferred from the procedural similarity between patent reexamination and patent prosecution, the original process of patent application and issuance. ${ }^{26}$ Patent prosecution is not the mere evaluation of a patent application. Rather, patent prosecution is also part of a patent's creation. In effect, section 132 of the Patent Code sets up a dialogue between the applicant and the

22. In re Etter, 756 F.2d 852, 857 (Fed. Cir. 1985). The Federal Circuit handles all appeals in patent cases, including appeals from federal district court decisions and PTO decisions. See 35 U.S.C. § 141 (1994) (providing for appeals from PTO Board of Appeals decisions); 28 U.S.C. $\$ 1295$ (1988) (granting the Federal Circuit appellate jurisdiction in all cases decided by federal district courts).

23. See 35 U.S.C. § 305 (1994).

24. Id.

25. In re Yamamoto, 740 F.2d 1569, 1572 (Fed. Cir. 1984).

26. Section 305 provides that "reexamination will be conducted according to the procedures established for initial examination under the provisions of sections 132 and 133 of this title." 35 U.S.C. § 305. 
PTO $^{27}$ If the PTO rejects any part of the application's claims, the PTO must give the applicant reasons for the rejection "together with such information and references as may be useful im judging of the propriety of continuing the prosecution." ${ }^{28}$ After receiving feedback from the PTO, the applicant may "persist" in his efforts to secure a patent. ${ }^{29}$ This persistence may involve the applicant amending the application and resubmitting it for further examination. ${ }^{30}$ The patent applicant often begins witl broad claim language, and narrows her claim language im response to the feedback provided by the PTO in its mitial rejection of the claim. In the practical world of patent practice, this dialogue between applicant and PTO is integral to the generation of the final patent document.

Current doctrine casts patent reexamination as an extension of the patent prosecution process. "In a very real sense," the Federal Circuit has stated, "the intent underlying reexamination is to "start over' in the PTO ...."31 To "start over" in the PTO means, literally, to return to the task of patent prosecution. "[T] he focus of [reexamination] is on curing defects which occurred during a proceeding in the PTO, which was responsible for original issuance of the patent." ${ }^{32}$ Reexamination's role is thus seen as largely curative rather than purely evaluative.

In a reexamination, the PTO is not viewed as the objective arbiter of a dispute between two parties, as is a court presiding over validity litigation. ${ }^{33}$ When a third party has requested reexamination, that party is not viewed as a hitigant or as a challenger. $^{34}$ It is the PTO, not the third-party requester, who takes on the role of patent challenger. ${ }^{35}$ The PTO, as both challenger and

27. See 35 U.S.C. \& 132 .

28. Id.

29. Id.

30. See id.

31. In re Etter, 756 F.2d at 857 .

32. Id. at 858.

33. Reexamination does not require a dispute between parties, but rather a "substantial new question of patentability." 35 U.S.C. $\$ 304$ (1994). This question may be raised by the patent owner. In fact, only $55 \%$ of reexamination requests made through June 30, 1994 were made by third parties. See ANNUAL REPORT, supra note 13, at 96.

34. See In re Etter, 756 F.2d at 857-58 (comparing and contrasting the role of the litigant challenging a patent in court to the role of the PTO conducting a reexamination).

35. See id. 
examiner, conducts "a subjective examination of claims in the light of prior art.".36

The court's description of reexamination as "subjective" is telling. The power to amend claims injects subjectivity into the PTO's reexamination. The examiner's subjectivity is not that of a biased reader. Rather, it is that of a concerned editor. The power to amend motivates the examiner to seek out probleins that miglit be eliminated through amendment. The court's description of reexamination as a "subjective" process is perfectly consistent with a conception of reexamination as part of the patent creating, or re-creating, process. The examiner does not look at the patent with an eye toward inaking a fixed determination of validity-he looks at the patent with an eye toward inaking it better.

However, one inust consider the patent-creating aspect of reexamination in light of reexamination's original purpose. If patent reexamination is to serve as an alternative to validity litigation, it inust play validity litigation's role of resolving disputes between parties. By proposing, through the Patent Reexamination Reform Act, an increased role for third-party requesters, Congress makes clear its desire that third parties cliallenging a patentee's riglit to a patent pursue their disputes with patent holders through reexamination rather than litigation. ${ }^{37}$ But reexamination cannot properly serve such a dispute-resolution role if the PTO's reexamination of the patent is conceived of as subjective ratlier than objective. The PTO should not remake the very thing it is supposed to evaluate. As long the power to amend injects subjectivity into the process, reexamination will be a troubling procedure, attempting at once to evaluate and to recreate the patent-two incompatible tasks.

\section{Problems IN the Relationship BetweEn REEXAMINATION AND LITIGATION}

When reexamination serves both as a method of patent evaluation and patent creation, the procedure's internal tension is revealed. The power to amend also causes tensions external to the procedure. Specifically, the power to amend creates two distinct problens in the relationship between reexamination and hitigation.

36. Id.

37. See supra note 21. 
First, the power to amend has led to standards of claim interpretation for reexamination procedures that differ from the standards of claim interpretation einployed for judicial proceedings. ${ }^{38}$ Second, the power to amend makes reexamination an extremely uncertain indicator of the respective rights of parties to a patent dispute.

\section{A. Dual Standards of Claim Interpretation}

Under Section 282 of the Patent Code, a litigated patent is presumed valid. ${ }^{39}$ This presumption of validity has been interpreted to dictate, $\mathrm{m}$ court proceedings, a particular burden of proof and a particular approach to patent claim interpretation. The party challenging a patent must establish invalidity by "clear and convincing evidence." ${ }^{\prime 40}$ Moreover, claim language "should be so construed, if possible, as to sustain [the patent's] validity." ${ }^{\text {"41 }}$ Thus, when claim language is susceptible of two interpretations, the narrower meaning will be adopted if necessary to avoid an overlap between the claim and the prior art. ${ }^{42}$

This presumption of validity, lowever, does not exist in reexamination proceedings. ${ }^{43}$ While the PTO has the imitial burden of establishing a prima facie case of invalidity, ${ }^{44}$ the requirement that invalidity be established by "clear and convincing evidence," does not apply to PTO reexamination. ${ }^{45}$ Instead, a claim may be rejected based upon a mere "preponderance of the evidence."

38. Robert E. Paulson introduced me to the particular problems associated with the dual standards of claim interpretation discussed in this subsection.

39. See 35 U.S.C. $\S 282$ (1994) ("A Patent shall be presumed valid. . . . The burden of estabhishing invalidity of a patent or any claim thereof shall rest on the party asserting such invalidity."); Blonder-Tongue Labs., Inc. v. University of Ill. Found., 402 U.S. 313, 335 (1971).

40. Innovative Scuba Concepts, Inc. v. Feder. Indus., Inc., 26 F.3d 1112, 1115 (Fed. Cir. 1994).

41. ACS Hosp. Sys., Inc. v. Montefiore Hosp., 732 F.2d 1572, 1577 (Fed. Cir. 1984).

42. See id.

43. In re Etter, 756 F.2d 852, 855-56 (Fed. Cir. 1985) (holding that $\$ 282$ does not apply to claims undergoing reexamination). In a persuasive concurrence to Etter, Judge Nies argues that $\S 282$ 's presumption of validity should apply to patent reexamination. Id. at 860 (Nies, J., concurring). A plain meaning approach to the Patent Code supports Judge Nies's position. Section 282 provides, simply, that "[a] patent shall be presumed valid." 35 U.S.C. $\$ 282$. No provision limits this presumption to actions in federal court. Had the drafters of the Act of 1980 wanted to deprive patent claims undergoing reexamination of this presumption of validity, they could have amended $\S 282$ to specifically exclude apphication of the presumption of validity in reexamination proceedings.

44. See HARMON, supra note 4 , at 571 .

45. In re Etter, 756 F.2d at $857-58$.

46. See In re Caveney, 761 F.2d 671, 674 (Fed. Cir. 1985). Caveney articulates a 
And unlike courts, which interpret claims narrowly so as to sustain their validity, the PTO gives claims their "broadest reasonable interpretation" when it reexamines a patent. ${ }^{47}$

The rule of broad claim interpretation follows froin the power to amend. "The PTO broadly interprets claims during examination of a patent application since the applicant may 'amend his claims to obtam protection commensurate with his actual contribution to the art." ${ }^{248}$ In explaiming the purpose of broad claim interpretation, the Federal Circuit implicitly focuses on the role of reexamination in making a better patent: "This approach serves the public interest by reducing the possibility that claims, finally allowed, will be given broader scope than is justified."49 Broad claim interpretation is more likely to call a patent claim into doubt because a broad claim is more likely to overlap with prior art. Such a rule is consistent with the function of creating a viable patent. The PTO's practice of giving claims their broadest reasonable ineaning during reexamination often forces a patentee to narrow her claims in order to clearly distinguisl them from the prior art. ${ }^{50}$ This narrowing of claim language, in response to a rule of imterpreting claims broadly, renders future findings of invalidity less likely.

Thus, the power to amend justifies a standard of claim interpretation in PTO reexamination that differs from the standard in district court proceedings. This situation creates an obvious forumshopping problem. A patent's validity could turn not on issues of the patent's language or the prior art, but rather on whetler the

standard for rejecting claims during the initial prosecution of a patent application. Because 35 U.S.C. $\$ 305$ dictates that reexamination follow the same procedures indicated for initial prosecution, it is safe to assume that "preponderance of the evidence" is also the standard for rejecting claims on reexamination. 35 U.S.C. $\$ \S 305,132,133$ (1994).

47. In re Yamamoto, 740 F.2d 1569, 1571 (Fed. Cir. 1984).

48. Id. (quoting In re Prater, 415 F.2d 1393, 1404-05, (1969)). In a reexamination proceeding where the power to amend is absent, the PTO applies a very different rule of claim interpretation. When the reexamined patent is expired, amendment is no longer an option.

[I]n reexamination proceedings in which the PTO is considering the patentability of claims of an expired patent which are not subject to amendnient ... [PTO policy] favors a construction of a patent claim that will render it valid, i.e., a narrow construction, over a broad construction that would render it invalid.

Ex parte Papst-Motoren, 1 U.S.P.Q. 2d (BNA) 1655, 1656, (B.P.A. 1986); see also Ex parte Bowles, 23 U.S.P.Q. 2d (BNA) 1015, 1017 (B.P.A. 1992).

49. Yamamoto, 740 F.2d at 1571.

50. See Robert P. Merges, Patent law and Policy: Cases and Materials 31 (1992) (noting that rejections by the examiner are nornally followed by attempts to narrow claim language). 
patent was presented to the PTO or to a district court. Consider further that decisions of both the PTO and a district court regarding patent validity are appealable to the same court, the Federal Circuit. $^{51}$ Thus, conceivably, the Federal Circuit could face two questions of the same patent's validity; the record before the court could contam comparisons to the same prior art references; the procedural posture could dictate the same standard of review for questions of claim interpretation; ${ }^{52}$ and yet the court would have to apply a different rule of claim interpretation depending on whether the action began in the PTO or in a district court. Such a difference could very easily lead the court to sustain a finding of validity on appeal from a district court and sustain a finding of invalidity on appeal from the PTO.

A dilemma of this exact sort surfaced in 1995 during a dispute over the meaning of the claim terin "integral."53 The patent for a hip prosthetic claimed a tip "integral" with the prosthetic's stem (the stem is the long, thin portion of a hip implant that rests in the interior of the thigh bone). The district court found the patent claim valid by defining "integral" narrowly to require that the tip move as if it were unitary with the stem. $^{54}$ In other words, the terin "integral" meant that there was no shppage where the tip and the stem met, and that the tip did not deforin when the stem moved but rather changed position in unison with it. ${ }^{55}$ However, the defendant had imitiated reexamination proceedings shortly before the end of the district court proceedings. Just prior to the judicial finding upholding the patent's vahdity, the PTO examiner, interpreting the claim broadly, reached the opposite conclusion. ${ }^{56}$ The examiner, applying the broadest reasonable ineaning, suggested that "integral" might mean merely "attached"

51. Compare 35 U.S.C. \& 141 (1994) (providing for appeals to the Federal Circuit from PTO Board of Appeals' decisions, including reexamination decisions) with 28 U.S.C. $\S 1295$ (1988) (giving the Federal Circuit appellate jurisdiction in all patent cases decided by district courts).

52. The Federal Circuit applies de novo review to questions of clain interpretation whether the appeal is from a district court or from the PTO. See Imazio Nursery, Inc. v. Dania Greenhouses, 69 F.3d 1560, 1569 (Fed. Cir. 1995) (reviewing district court's claim interpretation); In re Freeman, 30 F.3d 1459, 1464 (Fed. Cir. 1994) (reviewing the PTO's clain interpretation).

53. See Stryker Corp. v. Intermedics Orthopedics, 891 F. Supp. 751 (E.D.N.Y. 1995).

54. See id. at 778.

55. See id. at 778-79 (referring to and quoting expert testimony).

56. See id. at 806 . 
and thus the patent was invalid because earlier hip prosthetics liad tips attached to steins. ${ }^{57}$ Eventually, the PTO accepted the narrower definition adopted by the district court, but only because the word "integral" had been clearly defined in the patent's specification. ${ }^{58} \mathrm{Had}$ such specific evidence not been available, the validity of the patent might have hinged solely on the applicable rule of claim interpretation, that is, whetler the question was raised in the PTO or in the district court.

Results should turn not on the choice of forum, but rather on the merits of a particular case. ${ }^{59}$ It is the power to amend that justifies a rule of claim interpretation for PTO reexamination that differs from the rule applied in district court. This difference, in turn, creates forum advantages. Without the power to amend, the PTO would likely adopt the rule of narrow claim interpretation used in district court, ${ }^{60}$ and the current dual standard would disappear.

\section{B. Uncertainty and Reexamination's Inability to Substitute for Litigation}

The power to amend also undermines certainty about the validity of patents. Amendments introduce uncertainty because they raise new questions about the respective riglits of parties to a patent dispute. Specifically, the act of substantively amending a claim renders the claim retroactively impotent. In other words, a patent claim that lias been substantively amended is not enforceable prior to the date of amendment. ${ }^{61}$ Moreover, under the doc-

57. See File History, U.S. Patent 4,888,023 (on file with author).

58. See id.

59. The dual standard encourages forum shopping, a practice the Supreme Court has worked to discourage. See Hanna v. Plumer, 380 U.S. 460, 468 (1965) (explaining that one of the twin aims of the Erie rule was "discouragement of forum-shopping"). For example, although a patentee might prefer the relatively low cost of reexamination, she has a strong incentive to litigate the issue of her patent's validity in district court, where she will have the advantage of narrow claim interpretation, an advantage she will lack if she brings the issue of her patent's validity to the PTO.

60. See supra note 46.

61. Under 35 U.S.C. $\$ 307$ (1994) the effect of reexamination amendments is equivalent to the effect of reissue amendments as provided for by 35 U.S.C. $\S 252$ (1994). The first paragraph of 35 U.S.C. $\S 252$ has been interpreted to mean that if the amended claims are not legally "identical" to the claims of the original patent, "then the patentee lias no rights to enforce before the date of reissue." Kaufman Co. v. Lantech, Inc., 807 F.2d 970, 976 (Fed. Cir. 1986). Although the court here refers to reissue proceedings, the court is applying the same principle to reexamined patents. See id. 
trine of "intervening rights," the substantively amended claim is not enforceable agamst future infringing activities if those activities were already in progress prior to the date of the claim's amendment. $^{62}$ One must first ask, however, whether the amendment is "substantive." An amendment is not substantive merely because it changes a claim's language. ${ }^{63}$ Rather, an amendment is substantive only if it changes a claim's scope ${ }^{64}$ In practice, this is difficult to determine. But amendments that merely clarify a claim or make it more definite have not changed the claim's scope. ${ }^{65}$

Amendments thus create a dilemma for a patentee in a reexamination proceeding. The mere fact that a reexamination request was granted implies that there is a "substantial new question of patentability." "W6 "Whatever prior art has raised this "substantial new question" will be coinpared against the patent claim's "broadest reasonable imterpretation." 67 Any ambiguous claim language is more likely to survive the examiner's "broadest reasonable interpretation" if it is sharpened through amendınent. However, by amending, the patentee risks losing not only all rights to enforce the patent agamst infringement prior to the reexamination, she also risks losing rights to enforce the patent after the reexamination under the doctrine of intervening rights. ${ }^{68}$ Because reexamination does not empower the PTO to make any determination regarding infringement, the patentee will not know how amendinents have affected her rights until she brings a suit against an infringer. ${ }^{69}$

The power to amend during reexamination also creates uncertainty for third-party requestors. The third-party requestor often wants to know whether his activity will infringe a valid patent. His

62. See 35 U.S.C. \& 252; HARMON, supra note 4, at 599-600, 603.

63. See Kaufman, 807 F.2d at 978 (rejecting argument that "any amendment made during the reexamination proceeding is substantive").

64. See HARMON, supra note 4, at 600 ("[ $\mathrm{I}] \mathrm{t}$ is the scope of the claim that must be identical, not that the identical words must be used.").

65. See Tennant Co. v. Hako Minuteman, Inc., 878 F.2d 1413, 1417 (Fed. Cir. 1989) (holding that addition of a word which merely makes the claim "more definite" without changing its scope does not substantively change the claim); Seattle Box Co. v. Industrial Crating \& Packing, 731 F.2d 818, 828 (Fed. Cir. 1984) (characterizing a change as substantive and "not a matter of a mere clarification of language").

66. 35 U.S.C. \& 304.

67. In re Yamamoto, 740 F.2d 1569, 1571 (Fed. Cir. 1984).

68. See supra text accompanying note 62; Kaufman $\mathrm{Co}$. v. Lantech, Inc., 807 F.2d 970, 977-78 (Fed. Cir. 1986).

69. See 35 U.S.C. $\S \S 301-07$ (1994). 
guide to this question is his analysis of the prior art and his interpretation of existing patent claims. However, he does not know whether the claims will be changed during reexamination. Furtherinore, if the claims are changed, he cannot be sure whether he has any inore rights to infringe the claims than he did before the reexamination proceeding. He only gains rights if the amendments were "substantive."" But whether the amendments were "substantive" is determined by the courts, not the PTO, and, like the patentee, the third-party requestor must await answers in future litigation. Ironically then, although reexamination should reduce litigation, the power to amend, by raising (and not answering) the question of whether an amendment is substantive, creates an entirely new litigation issue.

\section{Why the POWER to AMEND SHOUld Be ABOLISHed}

The power to amend frustrates the goals of patent reexamination by encouraging the use of reexamination as a strategic adjunct to litigation and by increasing uncertainty about the validity of patents. If the power to amend were abolished, several benefits could follow. The presumption of validity applied in court proceedings could also apply in reexamination. The presumption of validity lends authority to the government's issuance of a patent, and witlout it the PTO's issuance of a patent beconies less meaningful. Reexamination was supposed to bolster investor confidence in issued patents. ${ }^{71}$ However, under current doctrine, reexamination "start[s] over" the process of patent prosecution, as if the patent liad never been issued. ${ }^{72}$ Absent the power to amend, the PTO would likely apply the presumption of validity in reexamination proceedings, making the validity of existing patents less fragile. ${ }^{73}$

The power to amend also justifies a rule of claim interpretation different from that applied in court proceedings. Results may hinge not on the substantive merits of the case but imstead may turn, as a matter of law, on the choice of forum. If the power to amend were abolished, standards of claim interpretation could be

\footnotetext{
70. See supra notes $61-65$ and accompanying text.

71. See H.R. REP. No. 96-1307, supra note 6, at 4.

72. In re Etter, 756 F.2d 852, 857 (Fed. Cir. 1985); see supra text accompanying note

73. See supra note 46.
} 31. 
made uniform, discouraging forum-shopping and parallel proceedings.

On a more general level, the dual standard of claim interpretation resulting froin the power to amend contravenes the policies articulated in the Federal Circuit's opimion in Markman v. Westview Instruments, Inc. ${ }^{74}$ In Markman, the Federal Circuit held that patent claim interpretation is a matter of law, and therefore not submittable to a jury. ${ }^{75}$ The court explamed that construing claims as a matter of law was important because it assured that tribunals would "arrive at the true and consistent scope of the patent owner's rights."76 Tribunals could ascertain the "true and consistent scope" of the patentee's rights because they would be applying "estabhished rules of [claim] construction." The Supreme Court affirmed, resting its holding, in part, on the uniformity promoted by allocating claim interpretation to judges rather than juries. ${ }^{78}$ Because construing claims as a matter of law reinforces a consistent approach to claim interpretation, litigation disputes are less likely to arise. Consistent rules make it easier to determine in advance the results of a particular lawsuit and thus make the imitiation of the lawsuit less necessary. ${ }^{79}$

Under current doctrine, however, parties do not know in advance which standard of claim interpretation will be applied to questions of validity. The analysis of a patent turns on whether the question is presented to a court or to the PTO.$^{80}$ Moreover, if the question is presented to the PTO, confusion results not merely from a broad rule of claim interpretation, but also from uncertainty as to whether a patent will be amended, and what the legal imphications of those amendments will be. ${ }^{81}$ Thus the power to amend and its associated rules of claim construction undermine

74. 52 F.3d 967 (Fed. Cir. 1995), aff'd 116 S. Ct. 1384 (1996). Kenneth D. Sibley pointed out to me the relationship between a dual standard of claim interpretation and Markman.

75. See Markman, 52 F.3d at 979.

76. Id. at 979 n. 67.

77. Id.

78. See Markman v. Westview Instruments, Inc., 116 S.Ct. 1384, 1396 (1996).

79. Markman, 52 F.3d at 978-79 ("[Potential parties to a patent dispute] may understand what is the scope of the patent owner's rights by obtaiming the patent and prosecution history .... and applying established rules of construction to the language of the patent claim in the context of the patent.")

80. See supra text accompanying notes $39-60$.

81. See supra text accompanying notes 61-70. 
the policy of uniformity behind Markman's holding that claims be construed as a matter of law.

Two arguments may be raised against abolishing the power to amend. First, one may argue that the power to amend allows the patent document to be improved and thus more clearly interpreted by those who read it. However, this argument fails because the goal of clarifying a patent's meaning would be met even if the power to amend did not exist. The PTO's reexamination office action would itself serve as clarification of the patent's claims. ${ }^{82}$ Anyone who reviews the office action would liave a guide as to how the claims would actually be interpreted by a court. Without the power to amend, the PTO would apply a rule of narrow claim imterpretation. ${ }^{83}$ A rule of narrow claim interpretation would make the PTO office action a mucli inore useful guide both to the public and to courts because the PTO would be applying the same standards that would be applied by a court.

A second argument against abolishing the power to amend is that it allows a patentee to salvage his patent im the face of newly discovered prior art. A patent lolder may, through reexamination amendments, do more than merely clarify his claims. He unay narrow his claims "in order to distinguish the invention as claimed from the [newly cited] prior art." ${ }^{284}$ Such amendments may preserve a patent that would otherwise be lield invalid. However, amendments which change the scope of claims are already permitted through reissue proceedings. ${ }^{85}$ Reissue allows a patentee to correct, through amendment, a patent that would be "inoperative or invalid" for a number of reasons, imcludimg the improper scope of its claims. ${ }^{86} \mathrm{~A}$ reissue proceeding, unlike a reexamination proceeding, does not attempt to resolve disputes over patent validity. Reissue is merely an attempt to cure a defective patent. Thus the power to amend makes sense in the context of reissue proceedings, and the existence of reissue proceedings makes the power to

82. The PTO issues its initial disposition of a reexamination in the form of "Office actions." Patent and Trademark Office, Manual of Patent EXaMinng ProceDURE $\$ 2262$ (6th ed. 1995). Office actions must contain a detailed explanation of the examiner's decision. See id. \$§ 2262, 2271.

83. The PTO already applies a rule of narrow claim interpretation to the reexamination of expired patents, where the power to anend is absent. See supra note 45 .

84. 35 U.S.C. § 305 (1994).

85. 35 U.S.C. § 251 (1994).

86. Id. 
amend entirely unnecessary in the context of patent reexamination.

\section{CONCLUSION}

The pending Patent Reexamination Reform Act of 1995 takes a surface-level approach to reexamination reform. Legislators are aware of reexamination's ills. Specifically, they have considered reexamination's underutilization by third-party requestors and reexamination's misutilization by those who attempt to raise identical questions before courts and before the Patent and Trademark Office. ${ }^{87}$ The proposed legislation makes patent reexamination more attractive to third-party requestors and codifies principles of collateral estoppel.

Unfortunately, the proposed legislation leaves untouched the fundamental problems that prevent reexamination from providing an alternative to higation and imcreasing certainty regarding the validity of patents. Reexamination has failed in fulfilling its original goals because it has suffered from a confusion of procedural purpose. That is, patent reexamination's procedures, particularly the power to amend, promote an interested, subjective re-creation of patents by the PTO. Such an approach conflicts with reexamination's goal of providing an alternative to validity litigation. Litigation provides an objective evaluation of patent claims. Until patent reexamination does the same, it calmot adequately fulfill its goal of providing an alternative to hitigation. The purpose of the power to amend also conflicts with reexamination's goal of increasing certamty regarding patent vahidity. The power to amend promotes uncertainty because it justifies a rule of claim interpretation entirely different from that applied in court. Moreover, the power to amend increases uncertaimty by leaving open the question of whether and how a particular amendment will alter the rights of parties to a dispute.

In addition, the dual standard of claim interpretation resulting froin the power to amend claims conflicts with the current Congressional effort to codify a principle of collateral estoppel ${ }^{88} \mathrm{Col}-$ lateral estoppel only makes sense when it precludes multiple dis-

87. See S. 1070, 104th Cong. (1995), 141 CONG. REC. S10,655-02, S10,656 (daily ed. July 25, 1995) (statement of Sen. Hatch) (discussing third-party underuse and misuse of reexamination).

88. See supra text accompanying note 18-19. 
putes from arising over the same facts and under identical principles of law. However, under the current dual standard of claim interpretation, reexamination and litigation are, as the Federal Circuit stated in In re Etter, "distinct proceedings, with distinct parties, purposes, procedures, and outcomes." ness-which results froin the power to amend-calls into question the appropriateness of applying a principle of collateral estoppel to both proceedings.

Without the power to amend, reexamination becomes a more useful procedure. Because the PTO and courts would apply the same rules of interpretation, doctrinal confusion would be minimized. But inore importantly, reexamination would then give patentees and third parties a more accurate preview of validity litigation. Such a preview might help parties negotiate rather than litigate their disputes, thus reducing the "lengthy and expensive" patent hitigation at which Congress originally took aim..$^{90}$

89. 756 F.2d 852, 857 (Fed. Cir. 1985).

90. H.R. REP. No. 96-1307, supra note 6, at 4. 
